\title{
Development and Performance Evaluation of Very High Early Strength Geopolymer for Rapid Road Repair
}

\author{
Abideng Hawa, ${ }^{1}$ Danupon Tonnayopas, ${ }^{2}$ \\ Woraphot Prachasaree, ${ }^{1}$ and Pichai Taneerananon ${ }^{1}$ \\ ${ }^{1}$ Department of Civil Engineering, Prince of Songkla University, HatYai, Songkhla 90112, Thailand \\ ${ }^{2}$ Department of Mining and Materials Engineering, Prince of Songkla University, HatYai, Songkhla 90112, Thailand \\ Correspondence should be addressed to Abideng Hawa; abideng.hawa@gmail.com
}

Received 23 February 2013; Revised 11 July 2013; Accepted 13 July 2013

Academic Editor: Dachamir Hotza

Copyright (C) 2013 Abideng Hawa et al. This is an open access article distributed under the Creative Commons Attribution License, which permits unrestricted use, distribution, and reproduction in any medium, provided the original work is properly cited.

High early strength is the most important property of pavement repair materials to allow quick reopening to traffic. With this in mind, we have experimentally investigated geopolymers using low cost raw materials available in Thailand. The geopolymer mortar was metakaolin (MK), mixed with parawood ash (PWA, rubberwood ash) or oil palm ash (OPA) as binder agent. Rubberwood is often used as raw material for biomass power plants in Thailand, especially at latex glove factories and seafood factories, and burning rubberwood generates PWA. Both PWA and OPA are therefore low cost residual waste, locally available in mass quantities. The geopolymer samples were characterized for compressive strength, drying shrinkage, and bond strength to Portland cement mortar with slant shear test. The experimental design varied the contents of PWA and OPA and the heat curing time $(1,2$ and $4 \mathrm{~h})$ after hot mixture process. The hot mixture process resulted in very high early strength. In addition, we achieved high compressive strengths, low drying shrinkage, and very significant bond strength enhancement by use of the ashes.

\section{Introduction}

Many concrete infrastructures, such as concrete pavement, bridge decks, parking structures, highways, and airport runways, have high repair costs when damaged. This is partly because special very-rapid-setting materials are used to shorten the repair time in order to quickly get back to normal use. The materials for rapid road repair must have high early compressive strength, and include polyurethane polymer, epoxy polymer, thermosetting vinyl polymer, and magnesium polyphosphate.

Rapid concrete repair methods are of economic significance and therefore have been widely studied. Relatively recent extensive studies have taken place at the Center for Transportation Research of the University of Texas at Austin [1] and the Texas Transportation Institute at the Texas A\&M University [2]. Modified Portland cement has been investigated $[3,4]$ along with magnesia-phosphate $[5,6]$. These studies have emphasized rapid setting. The current study used materials locally available in Thailand, including waste streams, in the production of geopolymers for these applications.

Studied in materials science and engineering, the geopolymer process takes place by chemical reactions between aluminosilicate materials and alkaline solutions, under elevated curing temperatures. Common raw materials for geopolymer are fly ash and metakaolin containing $\mathrm{SiO}_{2}$ and $\mathrm{Al}_{2} \mathrm{O}_{3}$. The geopolymer benefits include high strength and high early strength [7]. However, some studies [8-10] have also assessed other mechanical properties such as the compressive strength at 1,7 , and 28 days. These other properties are not of primary importance in concrete pavement repair, with the priority on early opening to traffic.

The current study focuses on metakaolin (MK), with parawood ash (PWA, i.e., ash from rubberwood) or oil palm ash (OPA).

Little research is available on the utilization of PWA or OPA waste. In addition, the mechanical properties and behavior of MK-based geopolymers with PWA or OPA are still not well established or understood. Thus, further research is 


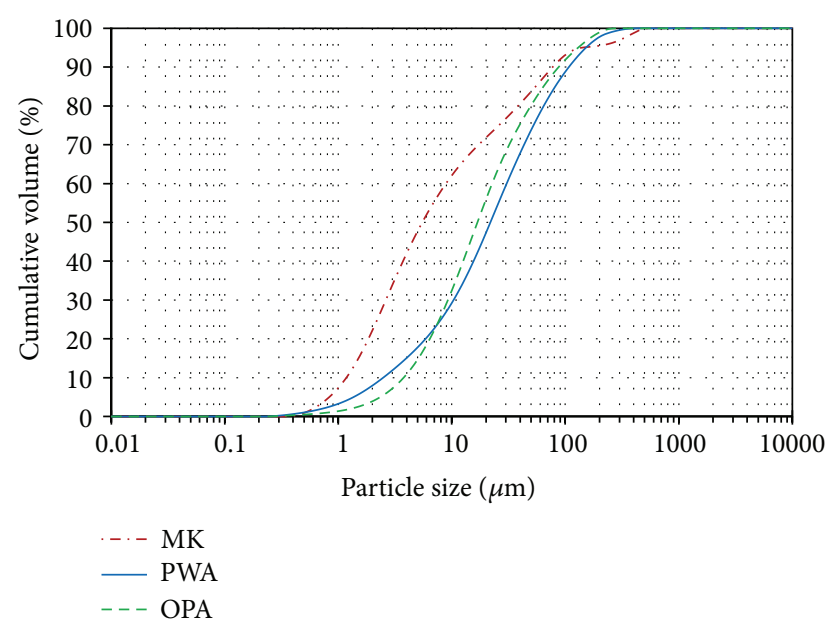

FIgURE 1: Particle size distributions of raw materials.

needed to evaluate the effects of PWA or OPA in geopolymer composite materials. The current study on MK-based geopolymers containing PWA or OPA addresses these gaps in knowledge about new environmentally friendly materials particularly for concrete pavement repair.

We have created and tested MK-based geopolymers containing PWA or OPA as partial replacements for MK. The amount of PWA ranged up to $30 \%$ and of OPA up to $15 \%$ by weight of MK. We also tested different heat curing times, so that all of the main factors influencing geopolymer properties were varied in the experimental design. Various key characteristics of concrete repair materials were determined for the geopolymer.

\section{Experimental Program}

2.1. Materials. The kaolin used in this study was calcined at $750^{\circ} \mathrm{C}$ for $2 \mathrm{~h}$ and used as Si-Al cementitious material. The chemical composition of the MK was analyzed using X-ray fluorescence (XRF); it had the main components $50.30 \% \mathrm{SiO}_{2}$ and $41.02 \% \mathrm{Al}_{2} \mathrm{O}_{3}$. Grinding the $\mathrm{MK}$ in a ball mill produced particles with mass-average size $d_{50}=6.31 \mu \mathrm{m}$ (Figure 1). Both chemical composition and physical properties of this MK are listed in Table 1.

PWA generated during the combustion of parawood for electricity production was collected from a biomass thermal power plant. The OPA used in this study was collected from a palm oil mill. Both the PWA and the OPA were ground in a ball mill for approximately $4 \mathrm{~h}$. The particle size distributions determined by laser scattering are shown in Figure 1: the $d_{50}$ values were $25.13 \mu \mathrm{m}$ for PWA and $19.31 \mu \mathrm{m}$ for OPA. The chemical compositions were analyzed by XRF. OPA had the main chemical components $13.84 \% \mathrm{~K}_{2} \mathrm{O}, 38.37 \% \mathrm{SiO}_{2}$, and $14.09 \% \mathrm{CaO}$ by weight, while PWA had similarly $16.11 \% \mathrm{~K}_{2} \mathrm{O}$ and $41.19 \% \mathrm{CaO}$. The chemical compositions and physical properties of PWA and OPA are listed in Table 1.

The alkaline activator used was a mixture of sodium hydroxide $(\mathrm{NaOH})$ in flakes of $98 \%$ purity, sodium silicate
TABLE 1: Chemical compositions (wt\%) and physical properties of cementitious materials used.

\begin{tabular}{|c|c|c|c|}
\hline Chemical compositions & MK & PWA & OPA \\
\hline $\mathrm{SiO}_{2}$ & 50.30 & 2.57 & 38.37 \\
\hline $\mathrm{Al}_{2} \mathrm{O}_{3}$ & 41.02 & 0.53 & 1.48 \\
\hline $\mathrm{Fe}_{2} \mathrm{O}_{3}$ & 1.05 & 0.56 & 3.01 \\
\hline $\mathrm{CaO}$ & 0.33 & 41.19 & 13.84 \\
\hline $\mathrm{TiO}_{2}$ & 1.50 & - & 0.21 \\
\hline $\mathrm{MgO}$ & - & 4.52 & 3.00 \\
\hline $\mathrm{K}_{2} \mathrm{O}$ & 4.08 & 16.11 & 14.09 \\
\hline $\mathrm{P}_{2} \mathrm{O}_{5}$ & - & 3.06 & 4.15 \\
\hline $\mathrm{SO}_{3}$ & - & 5.54 & 1.42 \\
\hline $\mathrm{Cl}$ & - & 0.82 & - \\
\hline $\mathrm{MaO}_{2}$ & - & 1.36 & - \\
\hline Loss on ignition (LOI) & 1.72 & 23.74 & 20.43 \\
\hline Specific surface area $\left(\mathrm{m}^{2} / \mathrm{g}\right) \mathrm{BET}$ & 13.61 & 8.71 & 13.06 \\
\hline$d_{10}(\mu \mathrm{m})$ & 1.352 & 2.860 & 4.321 \\
\hline$d_{50}(\mu \mathrm{m})$ & 6.308 & 25.128 & 19.305 \\
\hline$d_{90}(\mu \mathrm{m})$ & 88.803 & 123.450 & 100.109 \\
\hline
\end{tabular}

$\left(\mathrm{Na}_{2} \mathrm{SiO}_{3}\right)$, and water. The sodium silicate solution contained $14.14 \% \mathrm{Na}_{2} \mathrm{O}, 27.67 \% \mathrm{SiO}_{2}$, and $56.28 \% \mathrm{H}_{2} \mathrm{O}$ by weight.

River sand was used as the fine aggregate inert component of the geopolymer mortars. The specific gravity of the river sand was 2.51 and the maximum size was $4.75 \mathrm{~mm}$. The water absorption of the river sand was $1.48 \%$, tested in accordance with ASTM C128 [11].

2.2. Mixed Proportions. Geopolymer mortars were prepared by mixing the raw materials (MK with PWA or OPA), river sand, and alkaline activators (sodium silicate, sodium hydroxide, and water). The alkaline activator was mixed first at $74 \pm 2^{\circ} \mathrm{C}$ from reaction heat. The final mixing of alkaline activator, reactive raw material, and river sand took place at $48 \pm 2^{\circ} \mathrm{C}$. These elevated temperatures were essential to fast setting. Details of the ingredient proportions and molar ratios are shown in Tables 2 and 3, respectively. The samples were mixed manually, not with a motorized mixer. The slurries were poured into acrylic $50 \times 50 \times 50 \mathrm{~mm}$ molds to set and form samples for compressive strength testing. The samples were compacted in accordance with ASTM 109/C109M [12]. Samples were also formed in acrylic $25 \times 25 \times 285 \mathrm{~mm}$ molds, compacted in accordance with ASTM C596 [13], for use in tests of drying shrinkage. The samples in acrylic molds were wrapped with polyvinyl sheets to prevent loss of moisture. All of the samples were heated in an electric oven at $80^{\circ} \mathrm{C}$ after casting. After curing for 1,2 , or $4 \mathrm{~h}$, they were removed from the oven. After unwrapping and demolding, the samples were stored at ambient temperature of $30 \pm 2^{\circ} \mathrm{C}$ with a relative humidity $70 \pm 5 \%$ until they were tested. The bond strength test samples were prepared in $50 \times 50 \times 50 \mathrm{~mm}$ acrylic molds slanted to give an interface at $45^{\circ}$ (Figure 2) against Portland cement mortar, which was cured at ambient temperature for 7 days. Afterwards, the geopolymer was added to these molds to from a cube with the set Portland cement. The molds 
TABLE 2: Mixed proportions of geopolymer mortars (by weight).

\begin{tabular}{|c|c|c|c|c|c|c|c|c|}
\hline Mix & MK (\%) & PWA (\%) & OPA (\%) & $\mathrm{SS} / \mathrm{N}$ ratio & $\mathrm{A} / \mathrm{R}$ ratio & $\mathrm{W} / \mathrm{R}$ ratio & $\mathrm{RS} / \mathrm{R}$ ratio & Heat curing (h) \\
\hline Control-1 & 100 & - & - & & & & & \\
\hline P10-1 & 90 & 10 & - & & & & & \\
\hline P20-1 & 80 & 20 & - & & & & & \\
\hline P30-1 & 70 & 30 & - & 2.5 & 0.83 & 0.45 & 3 & 1 \\
\hline O5-1 & 95 & - & 5 & & & & & \\
\hline O10-1 & 90 & - & 10 & & & & & \\
\hline O15-1 & 85 & - & 15 & & & & & \\
\hline Control-2 & 100 & - & - & & & & & \\
\hline $\mathrm{P} 10-2$ & 90 & 10 & - & & & & & \\
\hline P20-2 & 80 & 20 & - & & & & & \\
\hline P30-2 & 70 & 30 & - & 2.5 & 0.83 & 0.45 & 3 & 2 \\
\hline O5-2 & 95 & - & 5 & & & & & \\
\hline O10-2 & 90 & - & 10 & & & & & \\
\hline O15-2 & 85 & - & 15 & & & & & \\
\hline Control-4 & 100 & - & - & & & & & \\
\hline P10-4 & 90 & 10 & - & & & & & \\
\hline P20-4 & 80 & 20 & - & & & & & \\
\hline P30-4 & 70 & 30 & - & 2.5 & 0.83 & 0.45 & 3 & 4 \\
\hline O5-4 & 95 & - & 5 & & & & & \\
\hline O10-4 & 90 & - & 10 & & & & & \\
\hline O15-4 & 85 & - & 15 & & & & & \\
\hline
\end{tabular}

Note: SS: sodium silicate; N: sodium hydroxide; A: (SS + N);

R: raw materials (MK, PWA, and OPA); W: water; RS: river sand.

TABLE 3: Mixture formulations.

\begin{tabular}{lcccc}
\hline Sample & $\begin{array}{c}\mathrm{SiO}_{2} / \mathrm{Al}_{2} \mathrm{O}_{3} \\
\text { (molar ratio) }\end{array}$ & $\begin{array}{c}\mathrm{CaO} / \mathrm{SiO}_{2} \\
\text { (molar ratio) }\end{array}$ & $\begin{array}{c}\mathrm{Na}_{2} \mathrm{O} / \mathrm{SiO}_{2} \\
\text { (molar ratio) }\end{array}$ & $\begin{array}{c}\mathrm{H}_{2} \mathrm{O} / \mathrm{Na}_{2} \mathrm{O} \\
\text { (molar ratio) }\end{array}$ \\
\hline Control & 2.77 & 0.01 & 0.21 & 11.43 \\
P10 & 2.85 & 0.08 & 0.23 & 11.43 \\
P20 & 2.95 & 0.16 & 0.25 & 11.43 \\
P30 & 3.09 & 0.26 & 0.27 & 11.43 \\
O5 & 2.88 & 0.02 & 0.22 & 11.43 \\
O10 & 3.01 & 0.03 & 0.22 & 11.43 \\
O15 & 3.15 & 0.04 & 0.22 & 11.43 \\
\hline
\end{tabular}

were wrapped with polyvinyl sheet and heated to $80^{\circ} \mathrm{C}$. After curing for 1,2 , or $4 \mathrm{~h}$, the samples were unwrapped and demolded. They were stored at ambient temperature for $24 \mathrm{~h}$ and then tested.

2.3. Test Procedure. Geopolymer mortars were wrapped with polyvinyl sheets to prevent moisture loss, cured in an oven at $80^{\circ} \mathrm{C}$ for 1,2 , or $4 \mathrm{~h}$, and cooled at ambient temperature of $30 \pm 2^{\circ} \mathrm{C}$ with $70 \pm 5 \%$ relative humidity. The compressive strengths of geopolymer mortars were determined according to ASTM 109/C109M [12], using a universal testing machine at a loading rate of $5.00 \mathrm{~mm} / \mathrm{min}$. For each mixture, three cast samples were tested at each age of 2, 6, $24 \mathrm{~h}$, and 7 days.

The drying shrinkage was determined with a length comparator in accordance with ASTM C490 [14]. The geopolymer

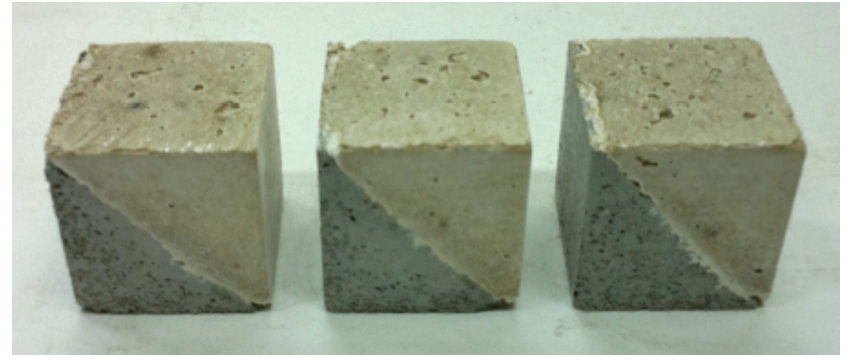

FIgURE 2: Typical specimens with geopolymer mortar bonded to Portland cement mortar.

mortars were prepared using 1,2 , or $4 \mathrm{~h}$ of curing at $80^{\circ} \mathrm{C}$. Measurements were taken up to 30 weeks of age after curing.

The bond strength between Portland cement mortar and geopolymer mortar was determined by a shear test, from $50 \times$ $50 \times 50 \mathrm{~mm}$ slant shear samples with interface line at $45^{\circ}$ (see Figure 2). The samples were tested under compression using the standard procedure for testing compressive strength. The bond strength was tested $24 \mathrm{~h}$ after heat curing, in ambient temperature. Bond failure of a slant shear sample is shown in Figure 3. The slant shear test has become the most widely accepted test for the bonding of repair materials to concrete [15]. However, there is no general standard available for this test $[15,16]$. 


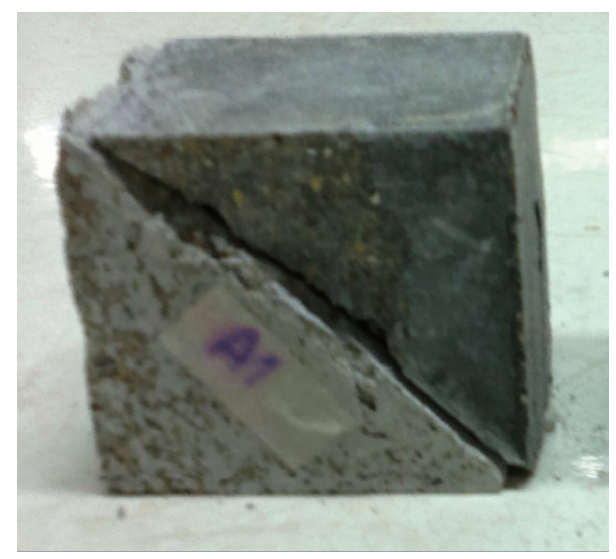

FIGURE 3: Slant shear sample after failure in compression test.

\section{Results and Discussion}

3.1. Compressive Strength. The effects of PWA or OPA content on the compressive strength of metakaolin-based geopolymer mortar are shown in Figures 4 to 8 . The early $2 \mathrm{~h}$ compressive strength is high, partly because the geopolymer mortars were prepared as a hot mixture before curing in an oven.

The compressive strengths for different mixtures at the observed ages are presented in Figure 4 . The early $2 \mathrm{~h}$ compressive strength ranged from $15 \mathrm{MPa}$ to $71 \mathrm{MPa}$, while the final observation at 7 days ranged from $42 \mathrm{MPa}$ to $70 \mathrm{MPa}$. The different curing times had no effect on the final compressive strength of these geopolymers.

The compressive strength of geopolymer mortars with PWA, heat-cured at $80^{\circ} \mathrm{C}$ for $1 \mathrm{~h}$, is shown in Figure 5. The compressive strength clearly decreased with PWA content, especially at $2 \mathrm{~h}$ observation time. This may partly be due to particle size effects $\left(d_{50} 6.31 \mu \mathrm{m}\right.$ of MK against $25.13 \mu \mathrm{m}$ of PWA); the greater surface area of finer particles makes them more active in polymerization [17]. Another contributing factor may be the reduction of $\mathrm{Si}$ and $\mathrm{Al}$ when $\mathrm{MK}$ is replaced with PWA. The $\mathrm{CaO}$ in PWA did not participate in geopolymerization and may have hydrated slowly. Winnefeld et al. [18] found that the lower strength incurred by high calcium content may in part be caused by poor reactivity with alkaline activators in fly-ash-based geopolymers. Test results confirmed that adding $\mathrm{CaO}$ into raw materials decreased compressive strength. Promising results have also been reported [19] for a curing temperature of $70^{\circ} \mathrm{C}$.

Compressive strengths with OPA, heat-cured at $80^{\circ} \mathrm{C}$ for $1 \mathrm{~h}$, are shown in Figure 6. The compressive strengths again decrease with OPA content, but at 5\% OPA the final 7day strength remains unchanged. The compressive strength values remain acceptable also at OPA contents of $10 \%$ and $15 \%$. The main chemical component in $\mathrm{OPA}$ was $\mathrm{SiO}_{2}$, while PWA mainly had $\mathrm{CaO}$, partly causing the different effects on compressive strength. Also, the average particles size differs, and the smaller-sized OPA may be more reactive due to this [17].

The effects on compressive strength might also be explained with molar ratios $\left(\mathrm{SiO}_{2} / \mathrm{Al}_{2} \mathrm{O}_{3}\right)$. Figure 4 shows the variation in compressive strengths of the samples measured after heat curing. Assuming this ratio was the determining factor, the most favorable $\mathrm{SiO}_{2} / \mathrm{Al}_{2} \mathrm{O}_{3}$ molar ratios were in control and $\mathrm{O} 5$, these being $\mathrm{SiO}_{2} / \mathrm{Al}_{2} \mathrm{O}_{3}=2.77$ and 2.88, respectively. Chindaprasirt et al. [20] have reported similar trends, with $\mathrm{SiO}_{2} / \mathrm{Al}_{2} \mathrm{O}_{3}$ up to 2.87, for high calcium fly-ashbased geopolymer systems. However, adding OPA beyond the optimal amount decreases the compressive strength because it also contains $\mathrm{CaO}$. In addition, the compressive strength decreased with the amount of PWA (high $\mathrm{CaO}$ ). This is consistent with previous studies [19] on fly-ash-based geopolymers. Previous studies [20-22] have also suggested that the ratio $\mathrm{SiO}_{2} / \mathrm{Al}_{2} \mathrm{O}_{3}$ influences the properties of the geopolymer binders. Generally, the geopolymer binders have been prepared using fly ash and metakaolin, with the ratio $\mathrm{SiO}_{2} / \mathrm{Al}_{2} \mathrm{O}_{3}$ within the range from 2 to $4[20,21]$.

For all mixtures, long heat curing times increased the compressive strength observed at $2 \mathrm{~h}$ in ambient temperature. Heat curing may accelerate the degree of geopolymerization by encouraging the formation of mineral phases. For the samples cured for 1,2 , and $4 \mathrm{~h}$, with $10 \%$ PWA or OPA, the compressive strengths for up to 7 days of age are shown in Figures 7 and 8. The samples cured for 2 and $4 \mathrm{~h}$ did not develop dramatically higher long-term compressive strengths; instead, the prominent effects are in the early strength development. Furthermore, with 10\% OPA, the curing time only had a marginal effect; see Figure 8.

3.2. Drying Shrinkage. All geopolymer mortars were exposed to $30 \pm 2^{\circ} \mathrm{C}$ and $70 \pm 5 \%$ relative humidity for a prolonged time, up to 30 weeks. The drying shrinkages of all samples are presented in Figures 9 to 12. The drying shrinkage of control samples is lower than with 10\%, 20\%, and 30\% PWA (Figure 9.). The average particle size of PWA is larger than of MK and correlates negatively with the specific surface area. The geopolymer reaction was incomplete (see Figures 5 and 6) after heat curing at $80^{\circ} \mathrm{C}$ for $1 \mathrm{~h}$, but the excess water could not evaporate because the samples were wrapped with polyvinyl sheets. After carving off the polyvinyl sheet, the evaporation of pore water could take place; this is easier with large pores corresponding to coarser particles. This is how PWA content may contribute to the drying shrinkage and increase it relative to control samples. Also, OPA tends to increase drying shrinkage (Figure 10). In the control and with $5 \%, 10 \%$, or $15 \%$ OPA, drying shrinkage was rapid in the 1 to $8 \mathrm{~h}$ interval. Our MK-based geopolymer containing PWA or OPA had lower drying shrinkages than those reported for slag mortar with sodium silicate, sodium hydroxide, and sodium carbonate activators [23].

Figures 11 and 12 illustrate the drying shrinkage of geopolymer mortars containing 10\% PWA and 10\% OPA, respectively, heat-cured at $80^{\circ} \mathrm{C}$ for 1,2 , or $4 \mathrm{~h}$. The samples exhibited similar behavior, in terms of longer curing decreasing the drying shrinkage. The shrinkage of the samples containing $10 \%$ PWA is presented in Figure 11. With $4 \mathrm{~h}$ curing, there was less shrinkage than with shorter curing. The use of water in the geopolymerization reaction increases with curing time. The drying shrinkage of samples containing 10\% OPA is presented in Figure 12. The samples cured for 2 and $4 \mathrm{~h}$ had 


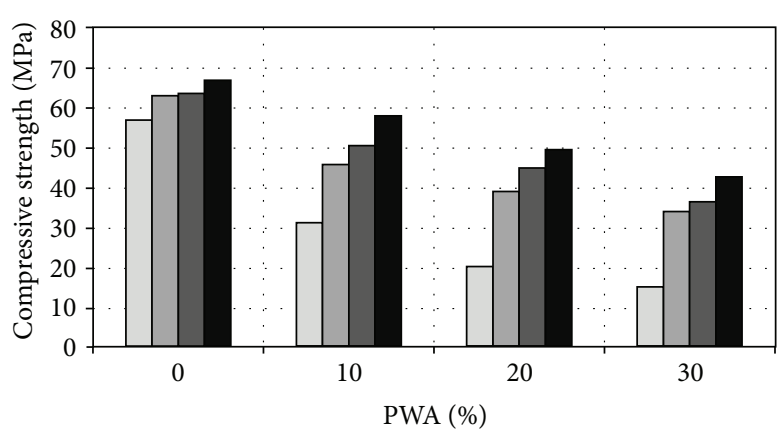

(a) PWA for $1 \mathrm{~h}$

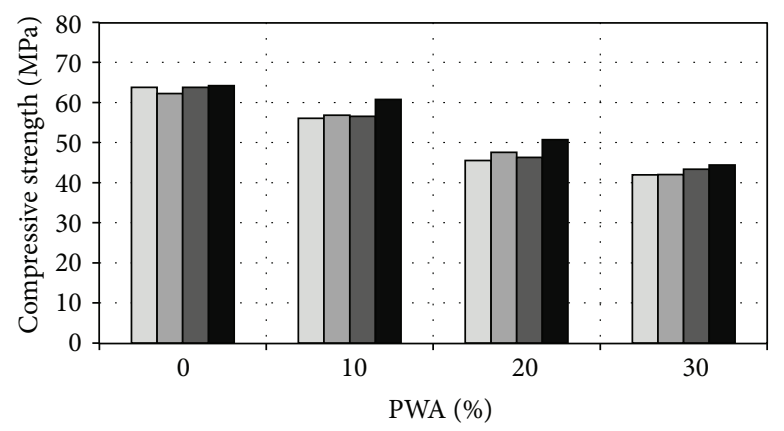

(c) PWA for $2 \mathrm{~h}$

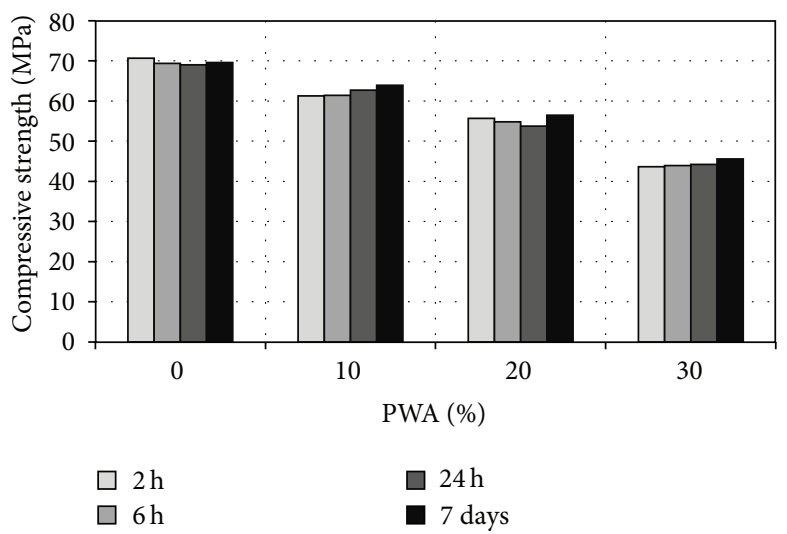

(e) PWA for $4 \mathrm{~h}$

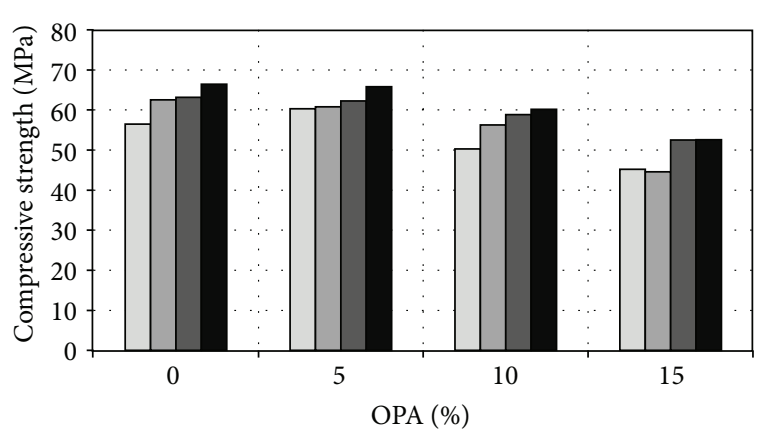

(b) OPA for $1 \mathrm{~h}$

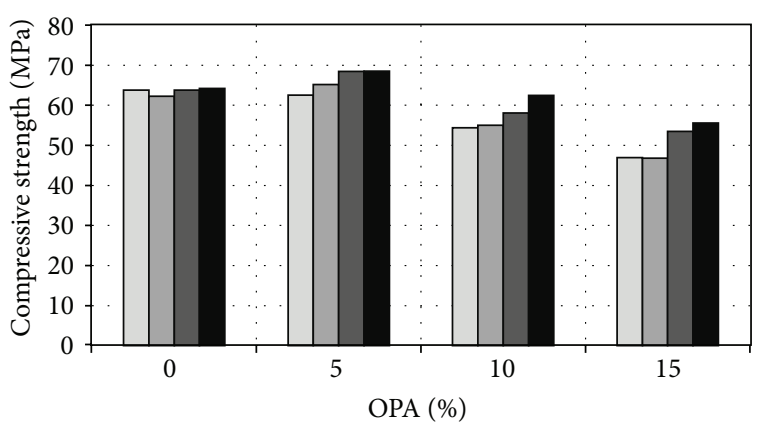

(d) OPA for $2 \mathrm{~h}$

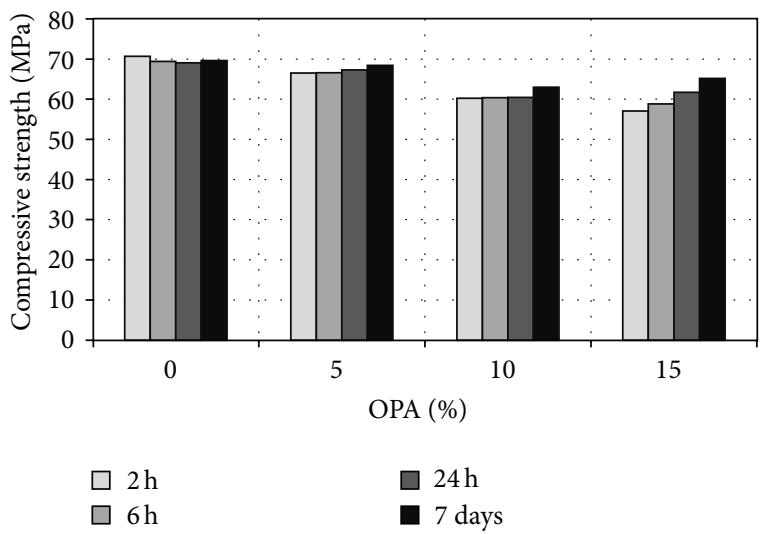

(f) OPA for $4 \mathrm{~h}$

FiguRE 4: Compressive strengths for different mixtures and curing times.

similar drying shrinkage values at all ages, with the shrinkage continuing throughout the observed 30 weeks. For specimens cured for $1 \mathrm{~h}$, the drying shrinkage was much higher at all ages than with the longer cure times. Again, longer cure times left less water for evaporation, due to higher extent of geopolymerization reactions that used up water.

3.3. Drying Shrinkage and Weight Loss. Figures 13 and 14 show the relationship between drying shrinkage and weight loss, expressed as percentage of initial weight, for geopolymer mortars containing 10\% PWA or 10\% OPA. At the longer curing times, the weight loss is smaller and so is the shrinkage. This may be due to the higher extent of geopolymerization reaction, in comparison with shorter curing time. Likely, the weight loss is mostly from evaporation of water.
3.4. Drying Shrinkage and Compressive Strength. The relationship of drying shrinkage with compressive strength at 7 days is shown in Figure 15. The high compressive strength samples have a stable aluminosilicate polymer structure [24] from geopolymerization, resisting shrinkage. Also, this mechanism may contribute to the effects of curing time on shrinkage.

3.5. Bond Strength. The results on bond strength to Portland cement mortar are shown in Figure 16. The bond strength improved with heat curing time for all formulations, and the samples containing PWA or OPA had dramatically higher slant shear strengths than the control sample with only MK, for all heat curing times tested. Particle size effects may contribute to this, as the larger particles (samples with 


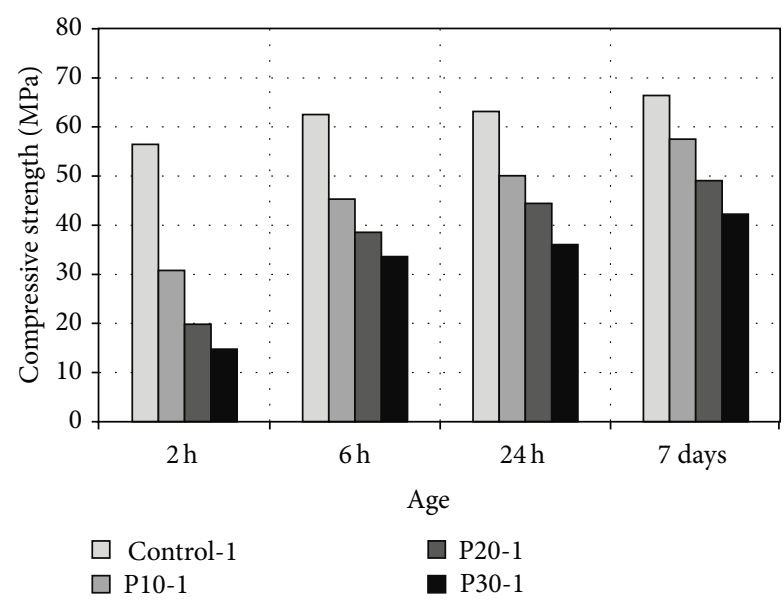

FIGURE 5: Compressive strengths of geopolymer mortars containing PWA, heat-cured at $80^{\circ} \mathrm{C}$ for $1 \mathrm{~h}$.

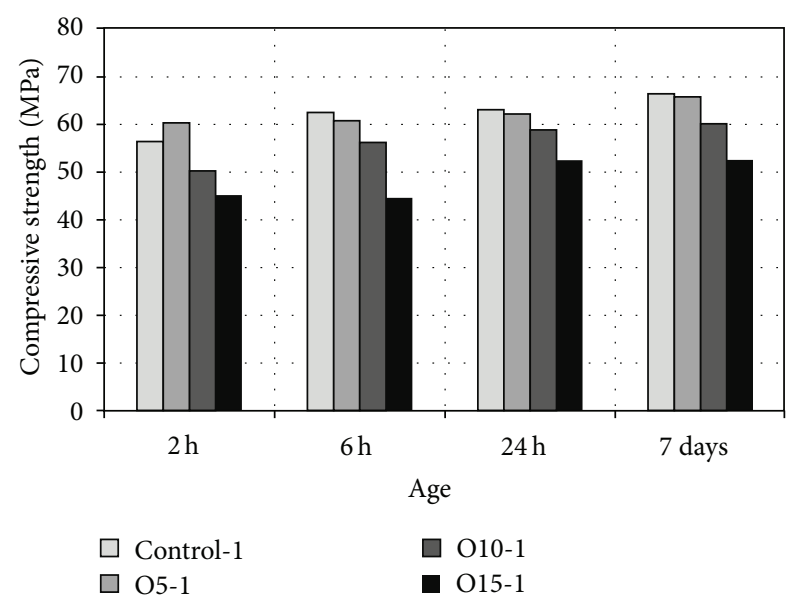

FIGURE 6: Compressive strengths of geopolymer mortars containing OPA, heat-cured at $80^{\circ} \mathrm{C}$ for $1 \mathrm{~h}$.
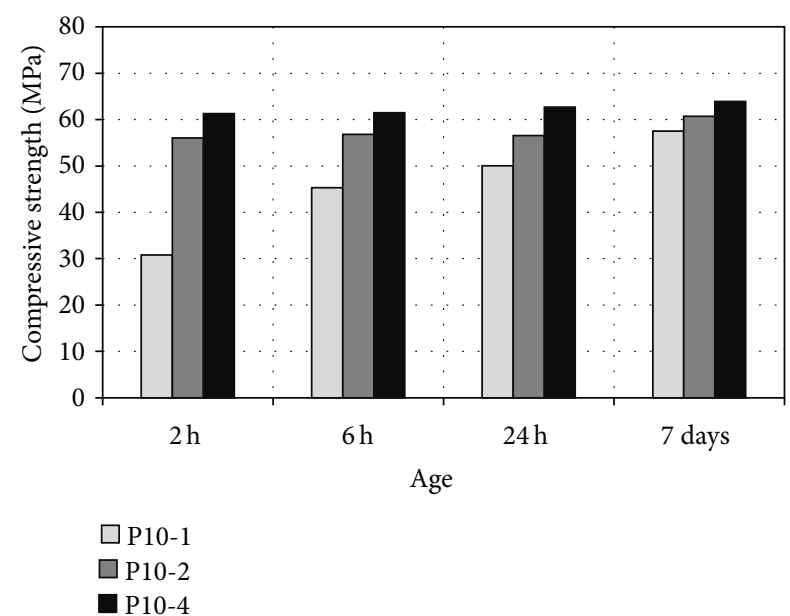

FIGURE 7: Compressive strength of geopolymer mortar containing $10 \%$ PWA.

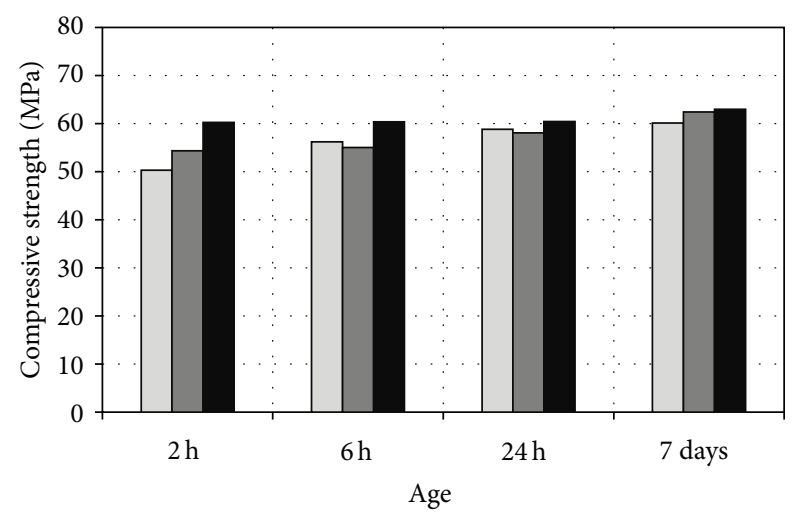

$\square \mathrm{O} 10-1$

$\square$ O10-2

ロ O10-4

FIGURE 8: Compressive strength of geopolymer mortar containing $10 \%$ OPA.

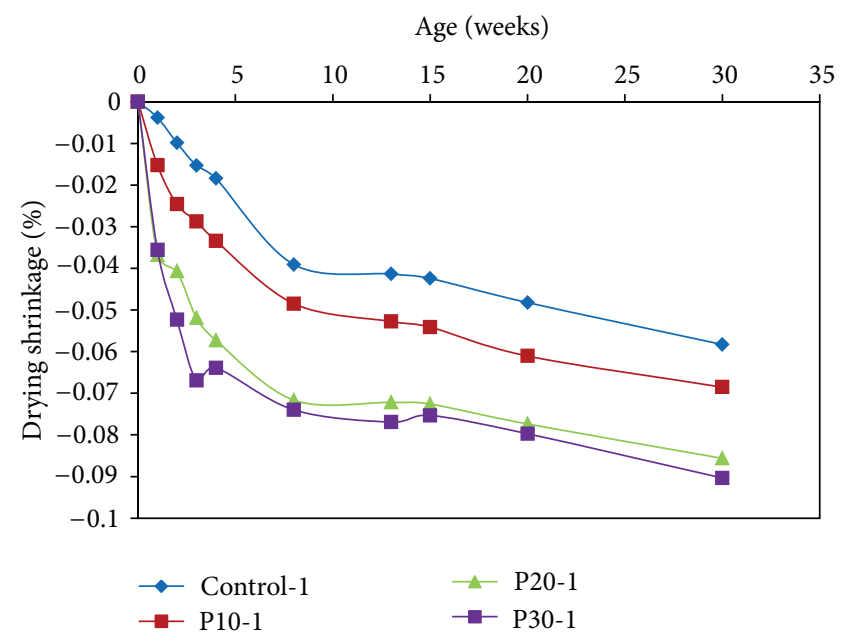

FIGURE 9: Drying shrinkages of geopolymer mortars containing PWA, heat-cured at $80^{\circ} \mathrm{C}$ for $1 \mathrm{~h}$.

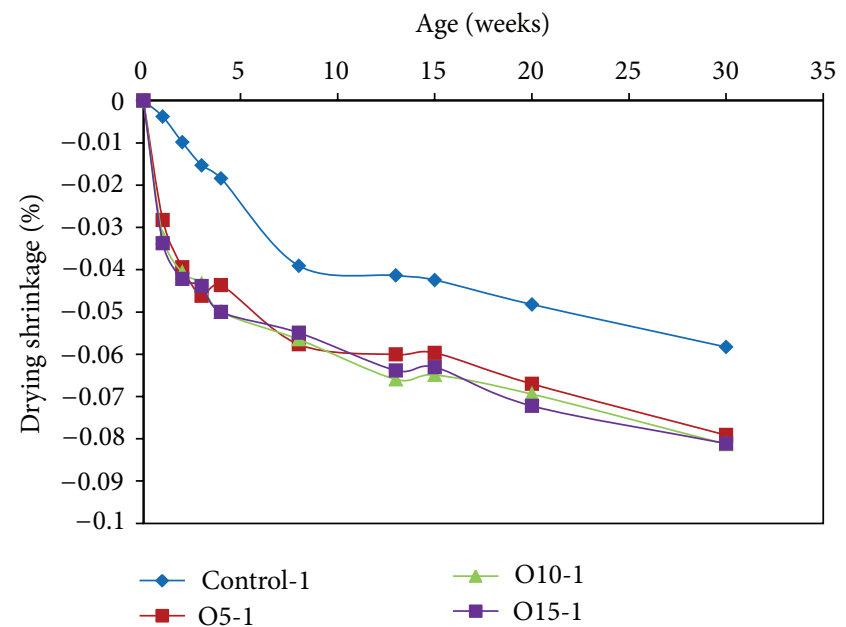

FIGURE 10: Drying shrinkages of geopolymer mortars containing $\mathrm{OPA}$, heat-cured at $80^{\circ} \mathrm{C}$ for $1 \mathrm{~h}$. 


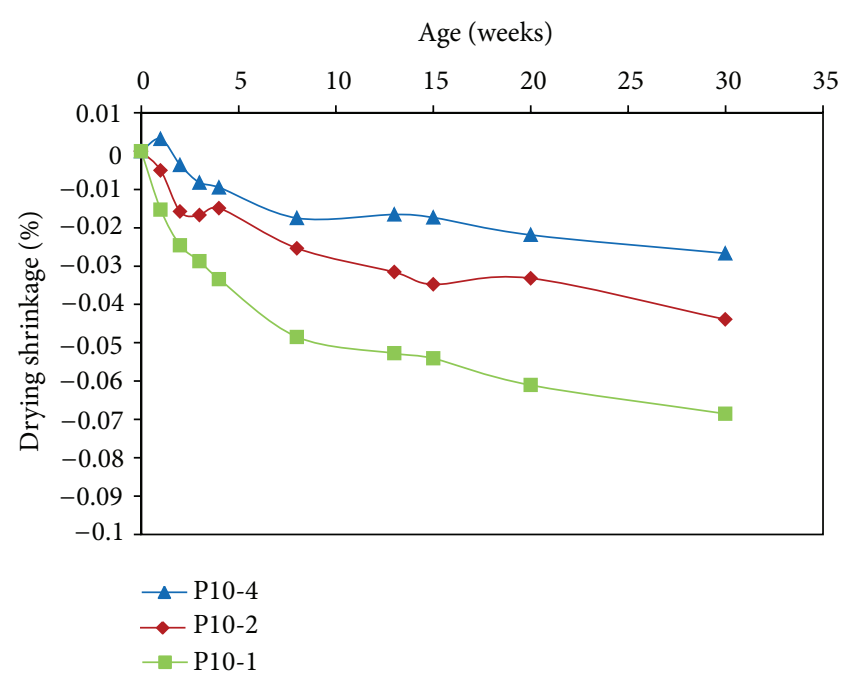

FIGURE 11: Drying shrinkage of geopolymer mortars containing 10\% PWA.

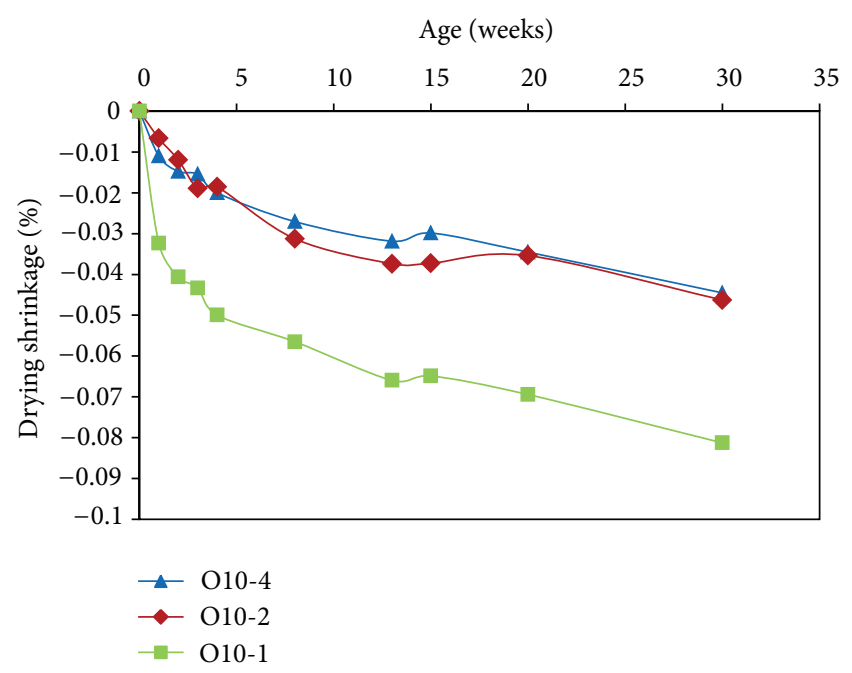

FIGURE 12: Drying shrinkage of geopolymer mortars containing 10\% OPA.

PWA and OPA) have a comparatively low specific surface area. Then, the slurries containing PWA and OPA may flow better, improving the surface contact with the OPC samples. Another potential mechanism is that the fast setting control samples might harden before fully developing surface bonds with OPC. Finally, there is the possibility of actual chemical reaction effects.

\section{Conclusions}

Geopolymer mortars from metakaolin with PWA or OPA were synthesized and studied, with the following main conclusions.

(i) OPA appears more advantageous than PWA, as a supplementary raw material in these geopolymers, due to overall better strength characteristics.

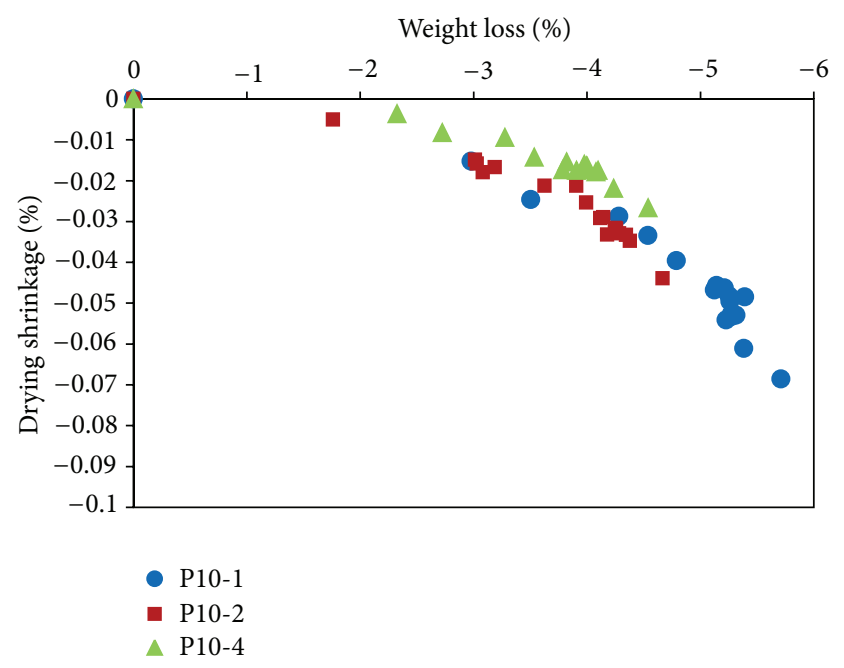

FIGURE 13: Relationship of weight loss on drying shrinkage with $10 \%$ PWA.

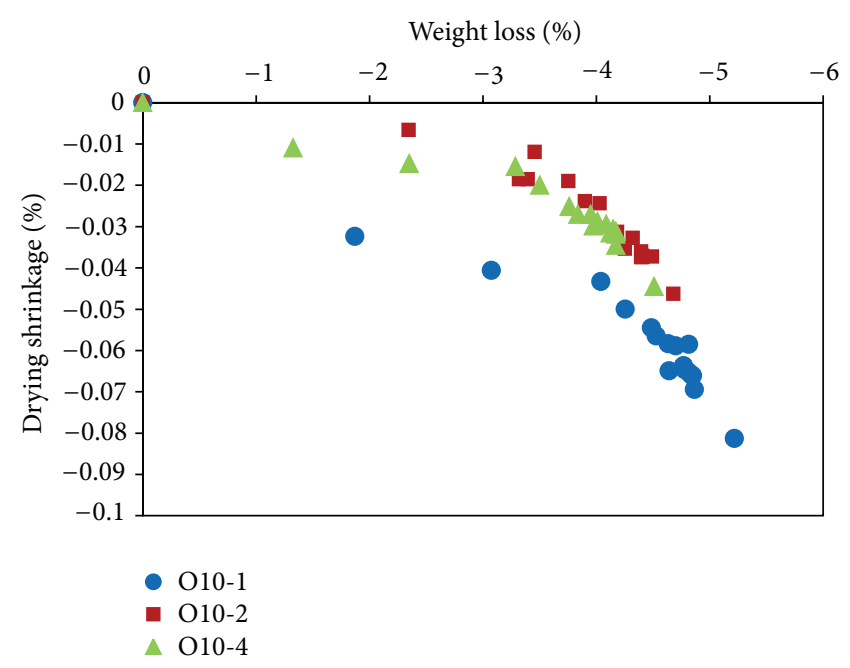

FIGURE 14: Relationship of weight loss on drying shrinkage with $10 \%$ OPA.

(ii) Both OPA and PWA dramatically (see Figure 16) increased the bond strength to Portland cement mortar and may be necessary components in the geopolymers for use in concrete repair.

(iii) Compressive strength of geopolymers can be improved by increased heat curing, here tested up to $4 \mathrm{~h}$. However, with only $10 \%$ of OPA, heat curing at $80^{\circ} \mathrm{C}$ for $1 \mathrm{~h}$ already showed maximal strength, while with $10 \%$ PWA, longer cure times affect especially early strength development.

(iv) Long heat curing times also decreased drying shrinkage, potentially due to the well-developed strength.

(v) The longer heat curing times also used more water in the geopolymerization process, reducing the amount left to evaporate and detectable as weight loss. 


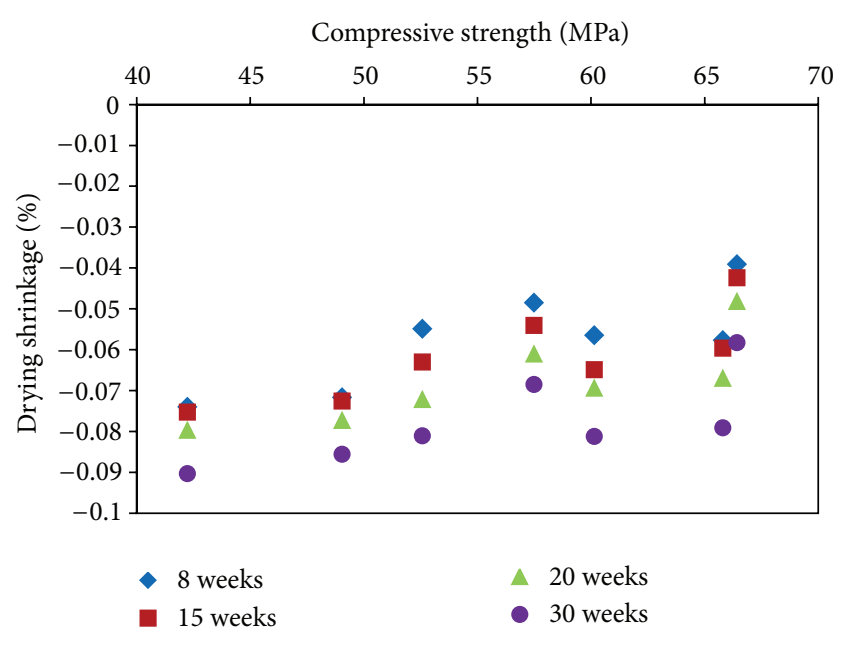

FIGURE 15: Relation between compressive strengths and drying shrinkage for samples heat-cured at $80^{\circ} \mathrm{C}$ for $1 \mathrm{~h}$.

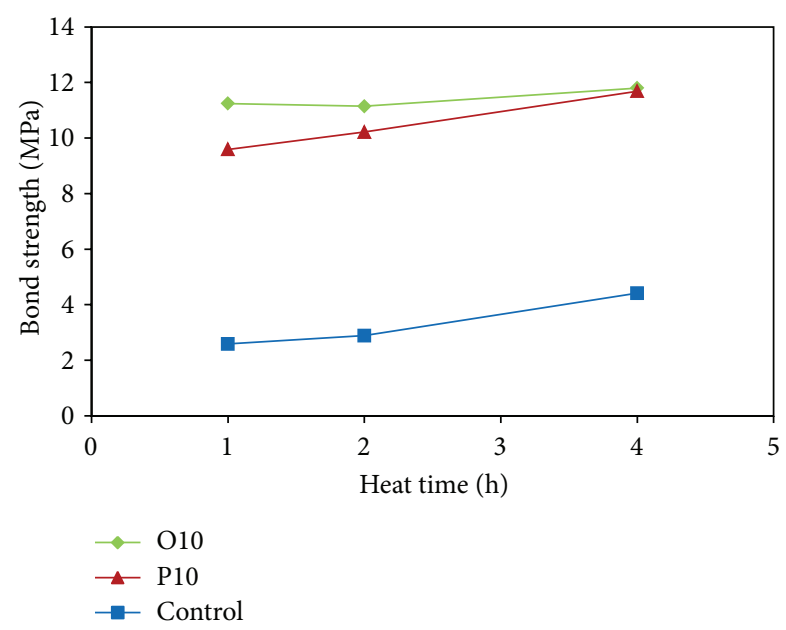

FIgURE 16: Bond strength to Portland cement mortar of select geopolymer samples, measured by compression test of slant shear.

The postcuring weight loss had a tight relationship to drying shrinkage.

Currently, geopolymer binders have not yet reached field applications. However, portable steam boilers may enable their practical use. Results from an ongoing field study of these geopolymers with high early strength will be the subject of a future publication, complementing the current laboratory study.

\section{Acknowledgments}

The authors gratefully acknowledge the financial support from the Office of the Higher Education Commission, and thesis research funding from Prince of Songkla University (PSU), Thailand, as well as the use of the facilities of the Department of Mining and Materials Engineering and Department of Civil Engineering, Prince of Songkla University. Dr. Seppo Karrila, from the Faculty of Science and Technology, is also acknowledged for comments and suggestions, as is the copyediting service of the Research and Development Office of PSU.

\section{References}

[1] S. M. Markey, D. P. Whitney, D. W. Fowler, S. I. Lee, A. K. Mukhopadhyay, and D. G. Zollinger, "Investigation of spall repair materials for concrete pavement," Tech. Rep. 0-51101, Center for Transportation Research, University of Texas at Austin, 2006.

[2] T. Tang and D. G. Zollinger, "Investigation of spall repair for concrete pavement," Tech. Rep. 2919-3, Texas Transportation Institute, Texas A\&M University, 1997.

[3] J.-P. Won, J.-M. Kim, S.-J. Lee, S.-W. Lee, and S.-K. Park, "Mix proportion of high-strength, roller-compacted, latex-modified rapid-set concrete for rapid road repair," Construction and Building Materials, vol. 25, no. 4, pp. 1796-1800, 2011.

[4] N. Buch, T. J. Van Dam, K. Peterson, and L. Sutter, "Evaluation of high-early strength PCC mixtures used in full depth repairs," Construction and Building Materials, vol. 22, no. 3, pp. 162-174, 2008.

[5] Q. Yang and X. Wu, "Factors influencing properties of phosphate cement-based binder for rapid repair of concrete," Cement and Concrete Research, vol. 29, no. 3, pp. 389-396, 1999.

[6] Q. Yang, B. Zhu, S. Zhang, and X. Wu, "Properties and applications of magnesia-phosphate cement mortar for rapid repair of concrete," Cement and Concrete Research, vol. 30, no. 11, pp. 1807-1813, 2000.

[7] F. J. Silva, A. F. Mathias, and C. Thaumaturgo, Evaluation of the Fracture Toughness in Poly (Sialate-Siloxo) Composite Matrix, Institute geopolymer, Saint-Quentin, France, 1999.

[8] P. Rovnaník, "Effect of curing temperature on the development of hard structure of metakaolin-based geopolymer," Construction and Building Materials, vol. 24, no. 7, pp. 1176-1183, 2010.

[9] Y. J. Zhang, S. Li, D. L. Xu et al., "A novel method for preparation of organic resins reinforced geopolymer composites," Journal of Materials Science, vol. 45, no. 5, pp. 1189-1192, 2010.

[10] X. Ma and Q. Rao, "Mechanical properties of high-performance lightweight aggregate concrete with inorganic polymers cement based on multiple minerals under uniaxial loading," Advances in Materials Science and Engineering, vol. 2012, Article ID 453035, 5 pages, 2012.

[11] ASTM C128, Standard Test Method for Specific Gravity and Absorption of Fine Aggregate, American Society for Testing and Materials, 1997.

[12] ASTM 109/C109M, Standard Test Method For Compressive Strength of Hydraulic Cement Mortar (Using 2-in. Or [50-Mm] Cube Specimens), American Society for Testing and Materials, 1998.

[13] ASTM C596, Standard Test Method for Drying Shrinkage of Mortar Containing Hydraulic Cement, American Society for Testing and Materials, 1996.

[14] ASTM C490, Standard Practice For Use of Apparatus For the Determination of Length Change of Hardened Cement Paste, Mortar, and Concrete, American Society for Testing and Materials, 1996.

[15] A. I. Abu-Tair, S. R. Rigden, and E. Burley, “Testing the bond between repair materials and concrete substrate," ACI Materials Journal, vol. 93, no. 6, pp. 553-558, 1996.

[16] S. Li, D. G. Geissert, G. C. Frantz, and J. E. Stephens, "Freezethaw bond durability of rapid-setting concrete repair materials," ACI Materials Journal, vol. 96, no. 2, pp. 242-249, 1999. 
[17] J. G. S. Van Jaarsveld, J. S. J. Van Deventer, and G. C. Lukey, “The characterisation of source materials in fly ash-based geopolymers," Materials Letters, vol. 57, no. 7, pp. 1272-1280, 2003.

[18] F. Winnefeld, A. Leemann, M. Lucuk, P. Svoboda, and M. Neuroth, "Assessment of phase formation in alkali activated low and high calcium fly ashes in building materials," Construction and Building Materials, vol. 24, no. 6, pp. 1086-1093, 2010.

[19] J. Temuujin, A. van Riessen, and R. Williams, "Influence of calcium compounds on the mechanical properties of fly ash geopolymer pastes," Journal of Hazardous Materials, vol. 167, no. 1-3, pp. 82-88, 2009.

[20] P. Chindaprasirt, P. De Silva, K. Sagoe-Crentsil, and S. Hanjitsuwan, "Effect of $\mathrm{SiO}_{2}$ and $\mathrm{Al}_{2} \mathrm{O}_{3}$ on the setting and hardening of high calcium fly ash-based geopolymer systems," Journal of Materials Science, pp. 1-8, 2012.

[21] P. D. Silva, K. Sagoe-Crenstil, and V. Sirivivatnanon, "Kinetics of geopolymerization: role of $\mathrm{Al}_{2} \mathrm{O}_{3}$ and $\mathrm{SiO}_{2}$," Cement and Concrete Research, vol. 37, no. 4, pp. 512-518, 2007.

[22] R. A. Fletcher, K. J. D. MacKenzie, C. L. Nicholson, and S. Shimada, "The composition range of aluminosilicate geopolymers," Journal of the European Ceramic Society, vol. 25, no. 9, pp. 14711477, 2005.

[23] D. C. Atiş, C. Bilim, Ö. Çelik, and O. Karahan, "Influence of activator on the strength and drying shrinkage of alkali-activated slag mortar," Construction and Building Materials, vol. 23, no. 1, pp. 548-555, 2009.

[24] T. Bakharev, "Durability of geopolymer materials in sodium and magnesium sulfate solutions," Cement and Concrete Research, vol. 35, no. 6, pp. 1233-1246, 2005. 

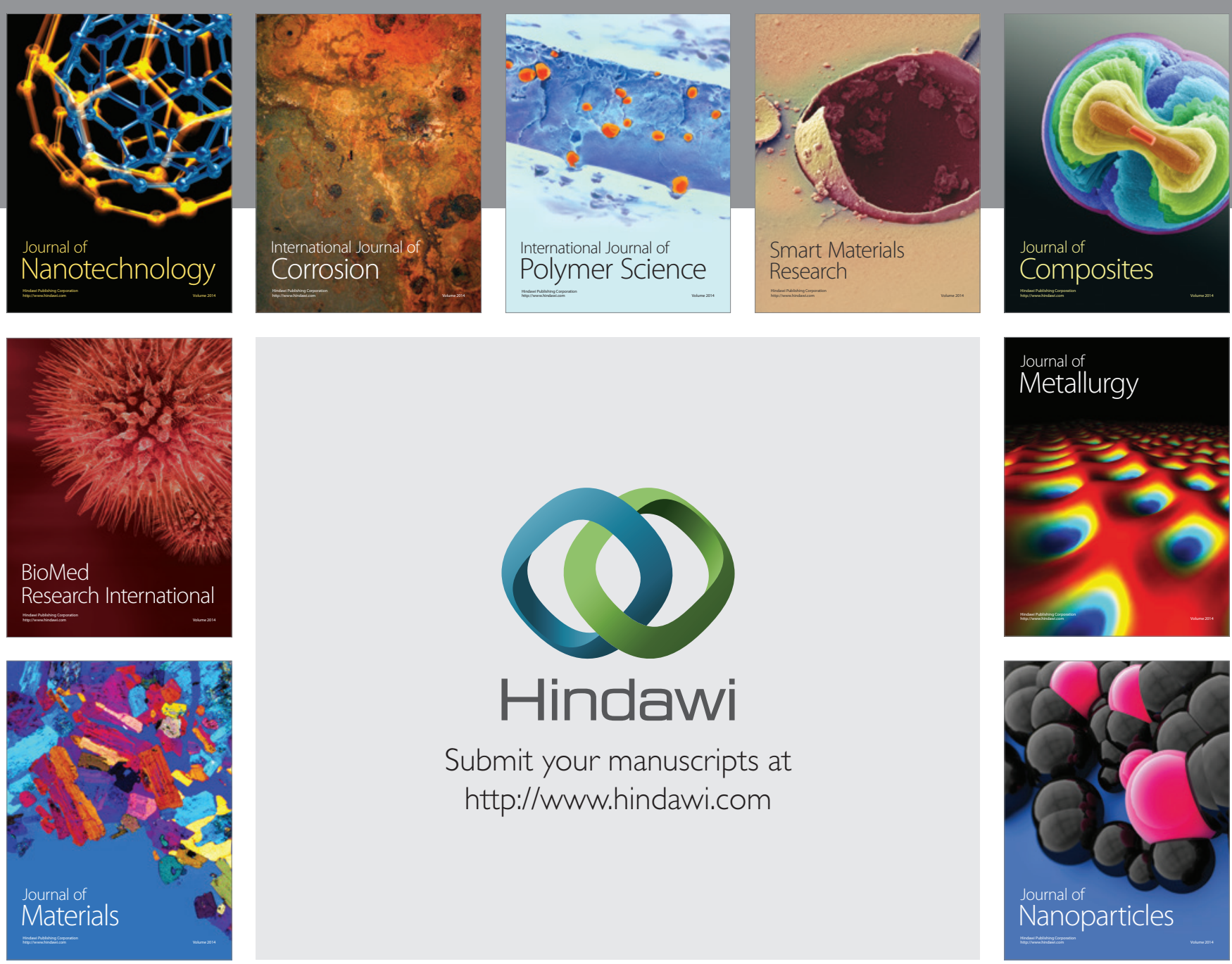

Submit your manuscripts at http://www.hindawi.com
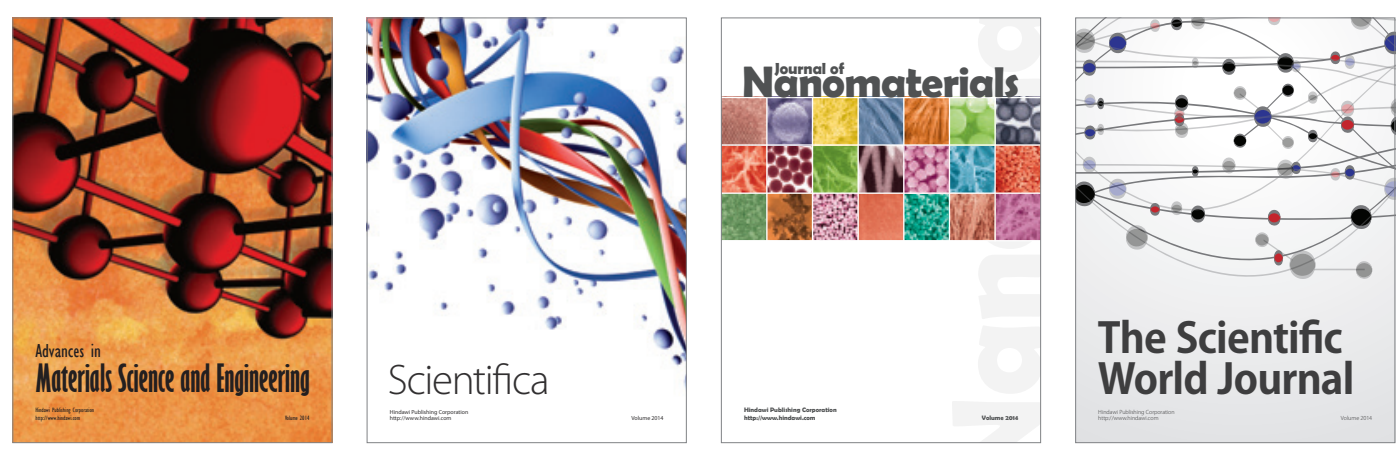

\section{The Scientific World Journal}
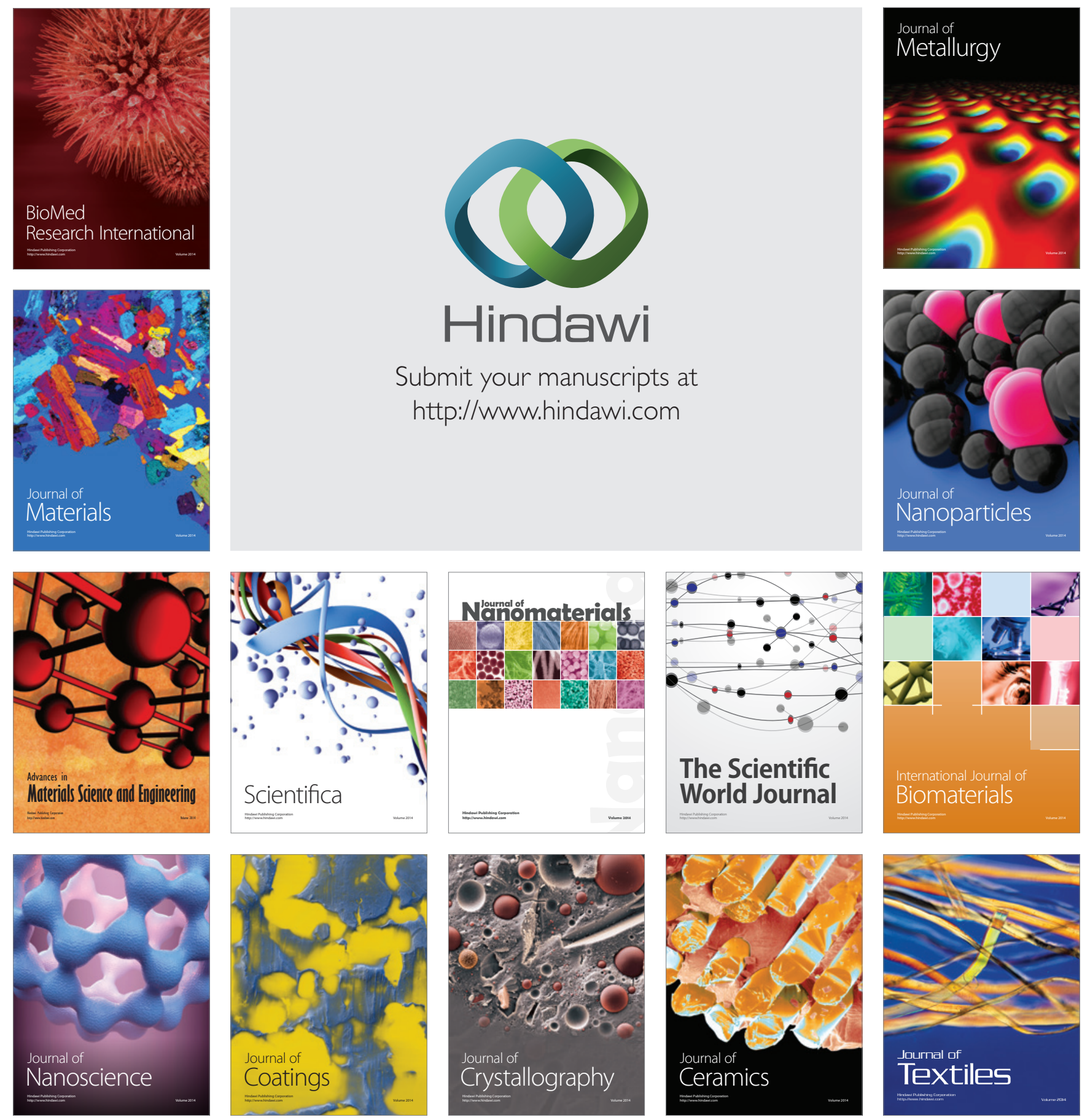